\title{
Alterations in cellular lipids may be responsible for the transient nature of the yeast heat shock response
}

\author{
Mahua T. Chatterjee, Seunath A. Khalawan and Brendan P. G. Curran
}

Author for correspondence: Brendan P. G. Curran. Tel: +44171 775 3013. Fax: +441819830973.
e-mail: B.Curran@qmw.ac.uk

School of Biological Sciences, Queen Mary and Westfield College, Mile End Road, London E1 4NS, UK

\begin{abstract}
The stress-sensing systems leading to the cellular heat shock response (HSR) and the mechanism responsible for the desensitizing of this response in stressacclimated cells are largely unknown. Here it is demonstrated that there is a close correlation between a $3^{\circ} \mathrm{C}$ increase in the temperature required for maximal activation of a heat-shock (HS)-inducible gene in Saccharomyces cerevisiae and an increase in the percentage of cellular unsaturated fatty acids when cells are subjected to extended periods of growth at $37^{\circ} \mathrm{C}$. The latter occurs with the same kinetics as HS gene down-regulation during a prolonged $\mathrm{HS}$ and is reversed by reacclimation to growth at $25^{\circ} \mathrm{C}$. The transient nature of the HS may therefore be due to a lipid-mediated decrease in cellular heat sensitivity. Further evidence that unsaturated fatty acids desensitize cells to heat, with a resultant down-regulation of the HSR, is provided by demonstrating a $9{ }^{\circ} \mathrm{C}$ increase in the temperature required for maximal induction of this HS-inducible gene in cells containing high levels of unsaturated fatty acids assimilated during anaerobic growth at $25^{\circ} \mathrm{C}$.
\end{abstract}

Keywords: Saccharomyces cerevisiae, lipids, transient heat shock response

\section{INTRODUCTION}

The yeast Saccharomyces cerevisiae, in common with all living organisms examined to date, possesses a set of heat shock (HS) genes. In yeast these are induced in cells exposed to a sublethal HS, and many are also induced by any one of a number of other stressing agents (for reviews, see Mager \& Ferreira, 1993; Parsell \& Lindquist, 1993). HS gene induction is dependent upon the activation of a HS transcription factor (Sorger \& Pelham, 1988; Wiederrecht et al., 1988) bound to HS elements (HSEs) (Pelham \& Bienz, 1982) in the promoters of these genes (for review, see Sorger, 1991), but the trigger responsible for HS transcription factor activation is unknown. The classical view of the HS response (HSR) is that stressing agents cause the accumulation of denatured proteins in the cell with a resultant induction of the genes responsible for HS protein production (for review, see Parsell \& Lindquist, 1993). An alternative view is that the temperature-sensing mechanism(s) is(are) intimately associated with membrane structure

Abbreviations: HS, heat shock; HSE, heat shock element; HSR, heat shock response.

We dedicate this paper to Mary Curran and to the memory of Séan Curran. and function. This is supported by a number of independent observations: plasma-membrane ATPase activity affects HS protein synthesis in yeast (Panaretou \& Piper, 1990); yeast thermotolerance increases with HS (Coote et al., 1994); and the activity of the lipidmodifying $\Delta 9$-desaturase enzyme affects the temperature for optimal HS gene expression in yeast (Carratu et al., 1996). These two views are not necessarily mutually exclusive (e.g. some cytoplasmic activities could be affected by heat-induced changes to membrane proteins and lipids) but the precise mechanism responsible for transducing heat stress into the intracellular message resulting in $\mathrm{HS}$ transcription factor activation has yet to be elucidated.

The HSR is generally transient in all organisms. At sublethal temperatures there is a significant diminution of the response within $1 \mathrm{~h}$ of induction and an eventual return to normal protein synthesis (Miller et al., 1979; Slater \& Craig, 1987; Sorger, 1990, 1991). This indicates that the temperature-sensing mechanism becomes desensitized by prolonged exposure to heat. Conversely, the temperature-sensing mechanism in yeast cells is rendered more sensitive in the presence of alcohols, the alcohol concentration required to elicit this increased sensitivity decreasing with increasing alcohol hydro- 
phobicity (Curran \& Khalawan, 1994). Neither of these observations lend support to a model of HS gene activation that involves the general thermal denaturation of cellular proteins as the trigger, but instead points to a sensor with a hydrophobic, dynamic nature that permits it to become differentially sensitive to the same temperature.

The yeast cell membrane is hydrophobic and dynamic, its lipid composition changing to adapt to the prevailing conditions (Hunter \& Rose, 1972; Suutari et al., 1990; Lloyd et al., 1993). In this study, we have monitored changes in the percentages of cellular unsaturated fatty acids during a sublethal HS and have demonstrated that the thermal inducibility of a HS-sensitive reporter gene is closely correlated with the percentage of unsaturated fatty acids present in the cell. This correlation is further substantiated by demonstrating an increase of up to $9{ }^{\circ} \mathrm{C}$ in the optimal activation temperature for the HSR in cells supplemented with high levels of unsaturated fatty acids under anaerobic growth metabolism. These results suggest that the transient nature of the HSR may be a manifestation of a lipid-mediated desensitization of the heat stress signal transduction mechanism. They are consistent with the recent findings of Carratu et al. (1996), which suggest that thermal stress is transduced into a cellular signal at the level of the membrane.

\section{METHODS}

Strains. Saccharomyces cerevisiae strain DBY747 (MATa leu2112 leu2-3 ura3 bis 3 trp1) was transformed to uracil prototrophy with the HS expression vector GA1695-HSE1 (a kind gift from Dr P. Sorger, University of California, USA) and the resulting transformant DBY747-HSE1 was used in this study. GA1695-HSE1 contains a single HSE sequence inserted in a disabled CYC1 promoter fused to the lacZ gene (Sorger \& Pelham, 1987). $\beta$-Galactosidase is not expressed at detectable levels in DBY747-HSE1 under normal conditions.

\section{Culture conditions}

Aerobic growth. DBY747-HSE1 was grown to exponential growth phase $\left(2 \times 10^{6}\right.$ cells $\left.^{-1}\right)$ in liquid minimal medium made to the specification of the formula of Wickerham (1951) supplemented with methionine $\left(20 \mathrm{mg} \mathrm{l}^{-1}\right)$, histidine $(20 \mathrm{mg}$ $\left.\mathrm{l}^{-1}\right)$, leucine $\left(30 \mathrm{mg} \mathrm{l}^{-1}\right)$ and tryptophan $\left(20 \mathrm{mg} \mathrm{l}^{-1}\right)$.

Cells were either grown at $25^{\circ} \mathrm{C}$ and acclimated in a $37^{\circ} \mathrm{C}$ shaking water-bath for $16 \mathrm{~h}$ (during which time cells were diluted with fresh selective medium to maintain exponential growth phase) or grown to exponential phase at $37^{\circ} \mathrm{C}$ and acclimated in a $25^{\circ} \mathrm{C}$ shaking water-bath for $16 \mathrm{~h}$ (during which time cells were diluted as described above). Samples were analysed for lipid and temperature profiles of HSE-lacZ induction at the specified time points.

Anaerobic growth. DBY747-HSE1 was grown on minimal medium plates to the specification of the original formula of Wickerham (1951) with the above amino acid supplements plus ergosterol $\left(5 \mathrm{mg} \mathrm{l}^{-1}\right)$ and either Tween $80\left(500 \mu \mathrm{ll}^{-1}\right)$ or linoleic acid $\left(300 \mu \mathrm{g} \mathrm{l}^{-1}\right)$ as specified. Plates were prepared under anaerobic conditions by inserting Petri dishes containing molten agar into an Oxoid anaerobic jar, previously purged with nitrogen, and adding two sachets of Oxoid Anaerogen anaerobic atmosphere generation system. The plates were removed the next day, inoculated by spreading approximately 500 cells from an exponentially growing liquid culture of DBY747-HSE1 $\left(2 \times 10^{6}\right.$ cells $\left.\mathrm{ml}^{-1}\right)$ and incubated at $25^{\circ} \mathrm{C}$ under the anaerobic conditions described above. Four days later the small colonies that appeared were washed into selective medium, to an $\mathrm{OD}_{600}$ of $0.05-0.10$ (Cecil spectrophotometer), harvested by centrifugation at 3000 r.p.m. for 3 min in an MSE bench-top centrifuge, washed twice with distilled water and resuspended in selective medium. Samples were taken for lipid and HSR profiles as specified below.

Reversion procedure. Colonies were washed from linoleicacid-supplemented plates after $4 \mathrm{~d}$ anaerobic growth into selective medium to an $\mathrm{OD}_{600}$ of $0 \cdot 05-0 \cdot 10$. The cells were harvested by centrifugation at $2000 \mathrm{~g}$ for $3 \mathrm{~min}$ in an MSE bench-top centrifuge, washed with distilled water and resuspended in selective medium. The cell suspension was acclimated in a shaking $25^{\circ} \mathrm{C}$ water-bath for $16 \mathrm{~h}$, during which time cells were diluted with selective medium to maintain exponential growth phase. Samples were analysed for lipid and HSR profiles at the specified time points as described below.

Determination of temperature profiles of HSE-lacZ induction. Aliquots $(10 \mathrm{ml})$ of exponentially growing cells were placed in $20 \mathrm{ml}$ Wickerham's liquid minimal media pre-heated to the stated temperature (in $250 \mathrm{ml}$ conical flasks) in shaking waterbaths and subjected to a $10 \mathrm{~min}$ HS. The flasks were then placed in a $25^{\circ} \mathrm{C}$ shaking water-bath for a further $50 \mathrm{~min}$ to allow $\beta$-galactosidase expression from the induced transcripts. $\beta$-Galactosidase activity was measured from a total cell extract as described previously (Curran \& Khalawan, 1994). One representative set of experimental results is presented for each temperature profile of HSE-lacZ expression in Figs 1(b), 2(b), $3(\mathrm{~b})$ and $4(\mathrm{~b})$. The absolute level of $\beta$-galactosidase varied between experiments but these profiles were reproduced in repeated separate experiments.

Determination of the cellular lipid profile. A modification of a previously described procedure (Hossack \& Rose, 1976) was used. Cells were harvested from $60 \mathrm{ml}$ cultures by centrifugation $\left(2000 \mathrm{~g}\right.$ for $3 \mathrm{~min}$ at $\left.25^{\circ} \mathrm{C}\right)$, washed twice with distilled water and the final pellet was resuspended in $400-500 \mu$ l distilled water. This suspension was added to a mortar, rapidly frozen in liquid nitrogen and ground with acid-washed sand. After the addition of $3 \mathrm{ml}$ chloroform/ methanol $(2: 1, \mathrm{v} / \mathrm{v})$ containing a few crystals of butylated hydroxytoluene, the lipids were extracted at $40^{\circ} \mathrm{C}$ for $1 \mathrm{~h}$. The upper layer was removed, the lower layer was washed by adding $2 \mathrm{ml}$ methanol/water $(1: 1, \mathrm{v} / \mathrm{v})$ and the upper layer was again removed. The remaining organic layer was evaporated to dryness in a stream of nitrogen gas and fatty acid methyl esters were prepared by refluxing the residue at $80-90^{\circ} \mathrm{C}$ for $1 \mathrm{~h}$ in $5 \mathrm{ml}$ concentrated sulphuric acid/ toluene/methanol $(1: 10: 20$, by vol.). The methyl esters were extracted into $2 \mathrm{ml}$ hexane, evaporated to dryness in a stream of nitrogen gas and dissolved in $20 \mu$ hexane for GLC analysis. Fatty acids were identified by their retention time relative to that of known standards on a packed column $(2 \mathrm{~m} \times 2 \mathrm{~mm})$ containing $10 \%$ CP-SIL 58 packing on chromosorb WHP 100-120 mesh (w/w). The relative percentage of each fatty acid was calculated by dividing the area underneath the peak by the total peak areas of both saturated and unsaturated fatty acids. The mean value from two separate experiments is presented in each figure in Results. The range is less than $10 \%$. 


\section{RESULTS}

There is an increase in cellular fatty acid unsaturation and in the temperature needed to elicit a maximal HSR during prolonged heat stress

The percentage of cellular unsaturated fatty acids increased by $9 \%$ when cells grown at $25^{\circ} \mathrm{C}$ were shifted to $37^{\circ} \mathrm{C}$ for $1 \mathrm{~h}$. It increased by a further $12 \%$ to $66 \%$ after $3 \mathrm{~h}$ and remained constant thereafter. This $21 \%$ increase in unsaturated fatty acids was the result of a decrease in C18:0 (18\%) and increases in C16:1 (7\%) and C18:1 (14\%) (Fig. 1a). The cells grown at $25^{\circ} \mathrm{C}$ and $37^{\circ} \mathrm{C}$ were differentially sensitive to HS. $\beta$-Galactosidase was minimally induced from the HS expression vector when cells grown at $25^{\circ} \mathrm{C}$ were exposed to $38^{\circ} \mathrm{C}$, this level increasing slightly at $39^{\circ} \mathrm{C}$, peaking at $40^{\circ} \mathrm{C}$ and declining to zero at $44^{\circ} \mathrm{C}$. In contrast, cells grown at $37^{\circ} \mathrm{C}$ had a lower sensitivity to heat: $\beta$-galactosidase was minimally induced between $38^{\circ} \mathrm{C}$ and $40^{\circ} \mathrm{C}$ (the temperature at which cells grown at $25^{\circ} \mathrm{C}$ responded maximally), and the maximal response shifted to $43^{\circ} \mathrm{C}$ (Fig. 1b).
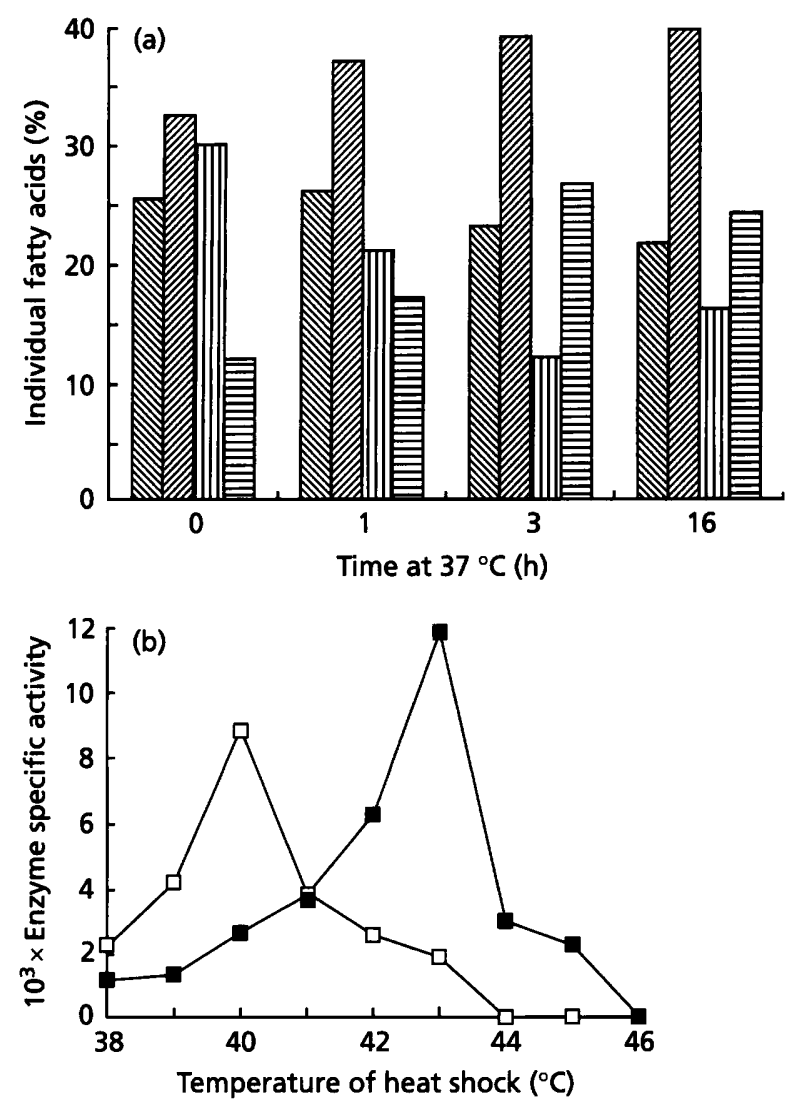

Fig. 1. (a) Percentage of individual fatty acids present in cells grown at $25^{\circ} \mathrm{C}$ and exposed to $37^{\circ} \mathrm{C}$ for 1,3 and $16 \mathrm{~h}$; the mean values from two separate experiments are shown (range less than $10 \%) . \mathbb{Q}, C 16: 0 ; \square, C 16: 1 ;$ 皿, C18:0; 目, C18:1. (b) Profile of HS-induced $\beta$-galactosidase expression from cells grown at $25^{\circ} \mathrm{C}$ and at $37^{\circ} \mathrm{C}$ for $16 \mathrm{~h}$. $\square, 0 \mathrm{~h} ; \mathrm{a}, 16 \mathrm{~h}$.


Fig. 2. (a) Percentage of individual fatty acids present in cells acclimated to $37^{\circ} \mathrm{C}$ and after growth at $25^{\circ} \mathrm{C}$ for 2, 4, 6 and $16 \mathrm{~h}$; the mean values from two separate experiments are shown (range less than 10\%). $\mathbb{Q}, C 16: 0 ; \bigotimes, C 16: 1 ;$ 四, C18:0; 目, C18:1. (b) Profile of HS-induced $\beta$-galactosidase expression at the same time points. $0,0 \mathrm{~h} ; 0,2 \mathrm{~h} ; \Delta, 4 \mathrm{~h} ; \square, 6 \mathrm{~h}$; $16 \mathrm{~h}$.

The percentage of unsaturated fatty acids and the temperature of the maximal HSR decline concomitantly as cells grown at $37^{\circ} \mathrm{C}$ reacclimatize to growth at $25^{\circ} \mathrm{C}$

The relationship between the degree of fatty acid unsaturation in the cell and the temperature of maximum HSR was maintained when cells grown at $37^{\circ} \mathrm{C}$ were reacclimated to growth at $25^{\circ} \mathrm{C}$ (Fig. 2a, b). Neither the percentage of unsaturated fatty acids present $(66 \%)$ nor the temperature required for maximal HS induction $\left(43^{\circ} \mathrm{C}\right)$ changed significantly during the first $2 \mathrm{~h}$. The percentage of unsaturated fatty acids fell by $10 \%$ to $56 \%$ over the next $2 \mathrm{~h}$, however, with the cells then responding maximally to heat stress at $42^{\circ} \mathrm{C}$. These values fell to $47 \%$ and $40^{\circ} \mathrm{C}$, respectively, over the next $2 \mathrm{~h}$ and remained relatively constant thereafter. The changes in the individual fatty acids were the reverse of what had occurred during the upshift in temperature. There were increases in C16:0 and C18:0 of $2 \%$ and $17 \%$, respectively, whereas $\mathrm{C} 16: 1$ and C18:1 both decreased by $10 \%$ (Fig. 2a). The lipid and HSR profiles did not differ significantly after $16 \mathrm{~h}$ at 

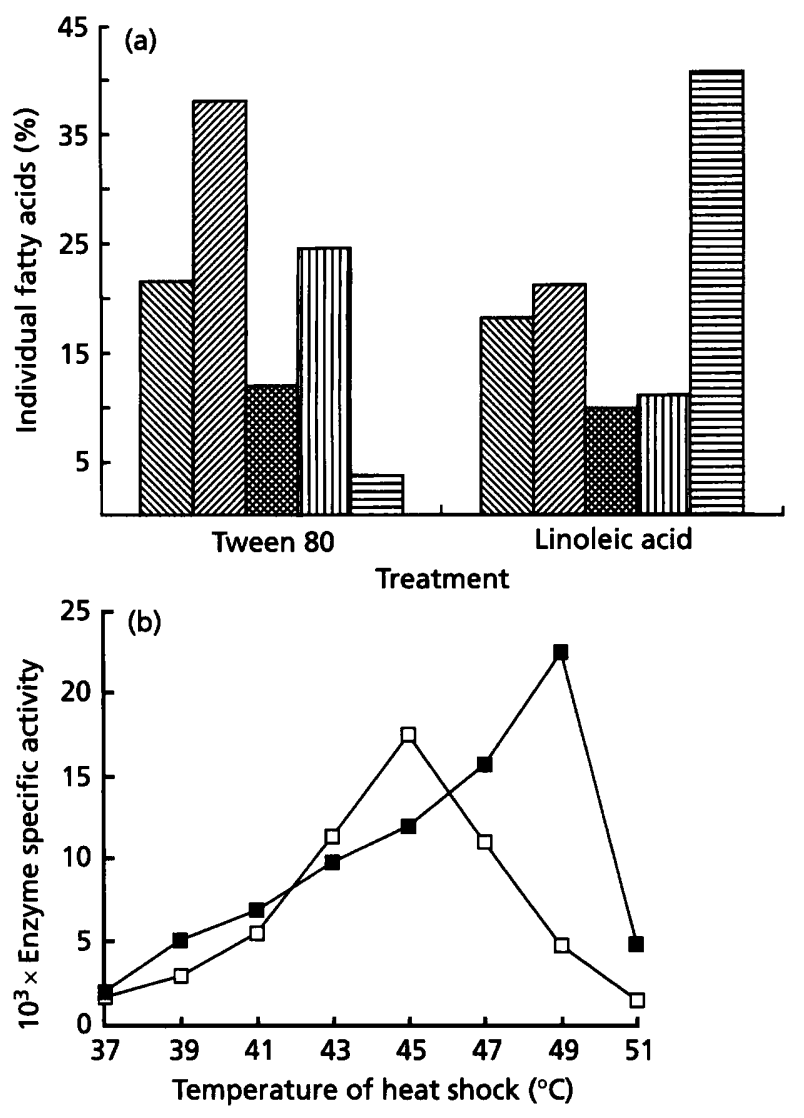

Fig. 3. (a) Percentage of individual fatty acids in cells grown at $25^{\circ} \mathrm{C}$ under anaerobic conditions in the presence of Tween 80 or linoleic acid; the mean values from two separate experiments are shown (range less than 10\%). $\mathbb{Q}, \mathrm{C16}: 0 ; \square$, C16:1; $\mathrm{B}, \mathrm{C18:0}$; 血, C18:1; 自, C18:2. (b) Profile of HS-induced $\beta$-galactosidase expression for the same cells. $\square$, Tween 80 ; $\square$, linoleic acid.

$25^{\circ} \mathrm{C}$ from those of cells grown at $25^{\circ} \mathrm{C}$, where the percentage of unsaturated fatty acids was $45 \%$ and the activation temperature for the maximal HSR was $40^{\circ} \mathrm{C}$ (compare Fig. 2a, b to Fig. 1a, b).

\section{The temperature of maximal HSR induction is affected by fatty acids assimilated during anaerobic growth}

The absolute requirement of anaerobically growing yeast cells for an external source of unsaturated fatty acid was exploited to produce cells with fatty acid profiles that were significantly different from one another and from cells grown under aerobic conditions at $25^{\circ} \mathrm{C}$. The percentage of unsaturated fatty acids in cells supplemented with Tween 80 was $66 \%$. The cells had $12 \%$ more C18:1 and 18\% less C18:0 than aerobically grown cells. They also contained $4 \% \mathrm{C} 18: 2$, which aerobically growing cells completely lack (compare Figs $1 \mathrm{a}$ and $3 \mathrm{a}$ ). There was minimal induction of $\beta$-galactosidase activity from these cells at $39^{\circ} \mathrm{C}$. This increased rapidly as the temperature was raised beyond $41^{\circ} \mathrm{C}$ with
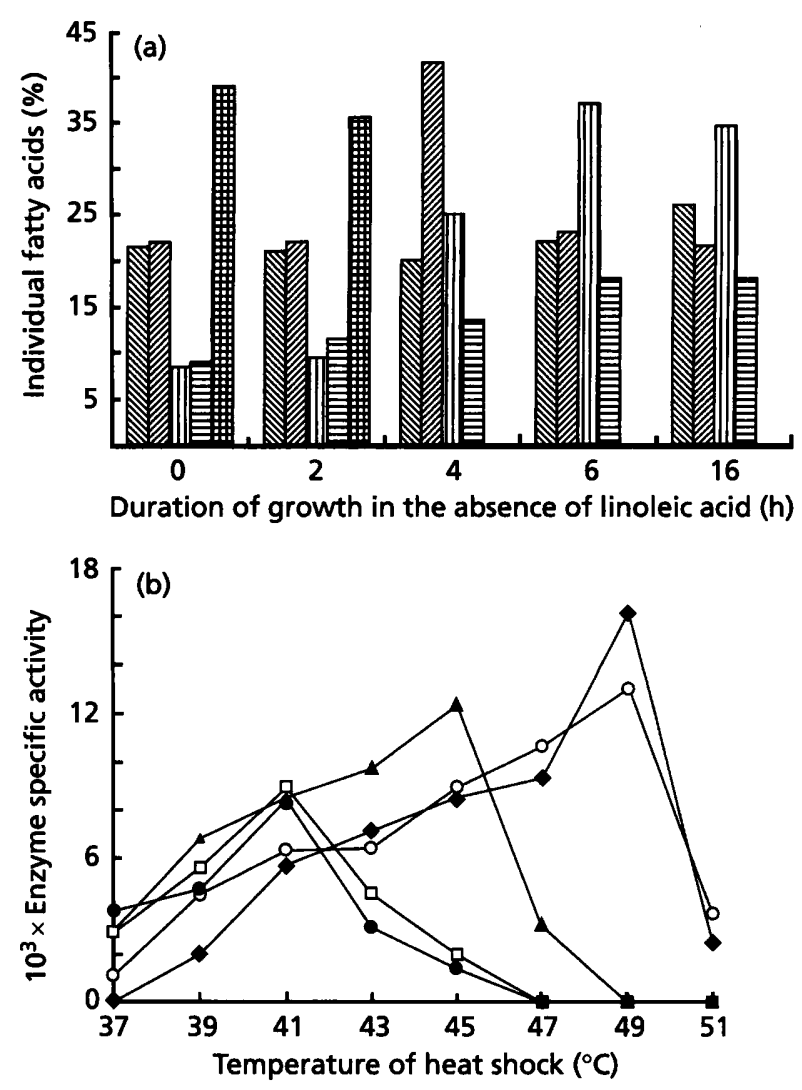

Fig. 4. (a) Percentage of individual fatty acids present in linoleic-acid-supplemented cells after growth at $25^{\circ} \mathrm{C}$ under aerobic metabolism for $0,2,4,6$ and $16 \mathrm{~h}$; the mean values from two separate experiments are shown (range less than

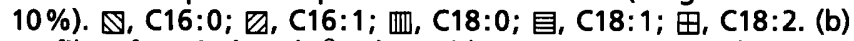
Profile of HS-induced $\beta$-galactosidase expression at the same time points. $\bullet, 0 \mathrm{~h} ; 0,2 \mathrm{~h} ; \Delta, 4 \mathrm{~h} ; \square, 6 \mathrm{~h} ; 0,16 \mathrm{~h}$.

peak induction occurring at $45^{\circ} \mathrm{C}$ (see Fig. 3b). Cells supplemented with linoleic acid (C18:2) contained $73 \%$ unsaturated fatty acids, $41 \%$ of which was linoleic acid (Fig. 3a), and required a significantly higher temperature for maximum induction of the HS reporter gene. There was minimal induction of $\beta$-galactosidase between $39^{\circ} \mathrm{C}$ and $41{ }^{\circ} \mathrm{C}$, and the level of induction increased slowly between $41^{\circ} \mathrm{C}$ and $45^{\circ} \mathrm{C}$ and finally peaked at $49^{\circ} \mathrm{C}$ (Fig. 3b).

\section{The percentage of unsaturated fatty acids and the temperature of maximal HSR induction decrease as linoleic-acid-containing cells return to aerobic growth}

There was a $29 \%$ decrease in lipid unsaturation and the activation temperature for the maximal HSR reverted to normal when linoleic-acid-supplemented cells were returned to aerobic growth in the absence of the supplement over a $6 \mathrm{~h}$ period (Fig. 4a, b). Initially these cells contained $70 \%$ unsaturated fatty acids (Fig. 4a) $(39 \%$ $\mathrm{C} 18: 2 ; 22 \% \mathrm{C} 16: 1 ; 9 \% \mathrm{C} 18: 1 ; 21 \% \mathrm{C} 16: 0$; and $9 \%$ 
C18:0) and responded maximally to heat at $49^{\circ} \mathrm{C}$ (Fig. $4 \mathrm{~b})$. For the first $2 \mathrm{~h}$ of aerobic growth in the absence of linoleic acid there was no significant change in either the lipid or HSR profiles but after $4 \mathrm{~h}$ the percentage of lipid saturation had fallen by $15 \%$ to $55 \%$ with a $36 \%$ decrease in C18:2, a $20 \%$ increase in C16:1, a $2 \%$ increase in C18:1 and a 16\% increase in C18:0 (Fig. 4a). At this point the cells responded maximally to heat at $45^{\circ} \mathrm{C}$ (Fig. 4b). After $6 \mathrm{~h}$ growth in the absence of linoleic acid, the percentage of unsaturated fatty acids decreased by a further $14 \%$ to $41 \%$ : there were further increases in $\mathrm{C} 18: 0(12 \%)$ and $\mathrm{C} 18: 1(4 \%)$ and a further decrease in C16:1 (19\%) (Fig. 4a). These cells had a greater responsiveness to heat with a HSR maximum of $41^{\circ} \mathrm{C}$ (Fig. $4 \mathrm{~b}$ ). Neither the lipid nor the HS induction profiles changed significantly thereafter (Fig. 4a, b)

\section{DISCUSSION}

The classical model of the HSR, that thermal denaturation of cellular proteins triggers HS gene induction (for a review, see Mager \& Ferreira, 1993), has difficulty explaining why the plasma-membrane ATPase activity affects the response (Panaretou \& Piper, 1990), why certain chemicals inhibit the response (Cheng \& Piper, 1994), how hydrophobic alcohols decrease the threshold temperature of HS gene activation (Curran \& Khalawan, 1994) and how changes in osmotic pressure induce HS gene expression (Varela et al., 1992; Lewis et al., 1995). It also fails to explain why HS genes are only transiently expressed during a sublethal HS (Miller et al., 1979; Slater \& Craig, 1987; Sorger, 1990, 1991) continuous heat stress should give rise to continual protein denaturation and hence continual HS gene activation.

This is the first paper to show, not only that there is a correlation between an increase in the percentage of unsaturated fatty acids in the cell and a desensitization of the temperature-sensing mechanism of $S$. cerevisiae, but that the increase in unsaturated fatty acid levels in cells exposed to a long-term heat stress occurs with kinetics consistent with those reported for the downregulation of HS gene induction which manifests as the transient HSR (Miller et al., 1979; Slater \& Craig, 1987; Sorger, 1990, 1991). Cellular unsaturated fatty acids increased by $9 \%$ within $1 \mathrm{~h}$ of the temperature upshift, by a further $12 \%$ within $3 \mathrm{~h}$ and remained constant thereafter (Fig. 1a). Yeast cells grown at $25^{\circ} \mathrm{C}$ had $45 \%$ unsaturated fatty acids and peak $\beta$-galactosidase induction at $40^{\circ} \mathrm{C}$ whereas cells grown at $37^{\circ} \mathrm{C}$ had $64 \%$ unsaturated fatty acids and peak induction at $43^{\circ} \mathrm{C}$ (Fig. $1 b)$. These results suggest that the transience of the HSR may be due to the desensitization of the signal leading to HS gene induction during a prolonged sublethal HS because an increase in the percentage of unsaturated fatty acids present in the cell results in the deactivation of the initial trigger.

This increase in the temperature of maximal HSR induction can be directly related to the decreased sensitivity of the HS gene activation system. The HS reporter gene was minimally induced at $40^{\circ} \mathrm{C}$ (the temperature of maximal induction for cells grown at $25^{\circ} \mathrm{C}$ ) for cells grown at $37^{\circ} \mathrm{C}$ (see Fig. 1b). Their HSR profile returned to normal over a $6 \mathrm{~h}$ period, as the percentage of unsaturated fatty acids fell by $25 \%$, when these cells were reacclimated to growth at $25^{\circ} \mathrm{C}$ (see Fig. 2a, b).

These results, which complement the findings of Carratu et al. (1996), who demonstrated that $\Delta 9$-desaturase activity affected the sensitivity of the HSR, were further substantiated by demonstrating an increase of $9^{\circ} \mathrm{C}$ in the HSR maximum in cells supplemented with high levels of unsaturated fatty acids during anaerobic growth (Fig. 3a, b). Linoleic-acid-supplemented cells containing $73 \%$ unsaturated fatty acids, $41 \%$ of which was the supplement, displayed maximal HSR at $49^{\circ} \mathrm{C}$. Within $6 \mathrm{~h}$ of aerobic growth in the absence of the fatty acid the cellular lipid profile approximated to that of cells grown aerobically at $25^{\circ} \mathrm{C}$ and the temperature of maximal HSR had fallen to $41^{\circ} \mathrm{C}$ (Fig. $4 \mathrm{a}, \mathrm{b}$ ). The fatty acid and HS profiles of linoleic-acid-supplemented cells were not simply artifacts of anaerobic growth because Tween-80-supplemented cells grown in the same anaerobic jar, on plates containing the same concentration of ergosterol, had a lower level of unsaturated fatty acids $(65 \%)$ and had a HSR maximum of $45^{\circ} \mathrm{C}, 4{ }^{\circ} \mathrm{C}$ lower than the linoleic-acid-supplemented cells (see Fig. 3a, b).

That a HS expression vector was differentially induced at the same temperature by cells containing different levels of unsaturated fatty acids suggests that the direct thermal denaturation of intracellular proteins is unlikely to be the initial trigger for the induction of the HSR. Instead, given that the lipid composition of the plasma membrane is a reflection of total cellular lipids (Thomas et al., 1978), that the plasma-membrane ATPase has been implicated in cellular heat tolerance (Panaretou \& Piper, 1990; Piper, 1993; Coote et al., 1994) and that an ionophore can cause concomitant changes in intracellular $\mathrm{pH}$ and $\mathrm{HS}$ gene induction (Weitzel et al., 1987), a more likely candidate is a fluctuation in the electrochemical gradient across the plasma membrane.

By demonstrating a correlation between an increase in fatty acid unsaturation and an increase in the temperature required for $\mathrm{HS}$ gene induction, this study lends strong support to the idea that a primary temperature sensor exists at the level of the membrane. Furthermore, by demonstrating that the temperature-sensing mechanism is reset in stress-acclimated yeast cells and that the percentage of unsaturated fatty acids increases in these cells with the kinetics reported for HS gene downregulation during a prolonged heat stress, the transient nature of the HSR can be explained by a lipid-mediated decrease in cellular heat sensitivity.

\section{ACKNOWLEDGEMENTS}

We thank Dr Virginia Bugeja for helpful discussions, Alan Scott for expert technical assistance with lipid analysis and Rebecca Burbidge for performing preliminary experiments. 


\section{REFERENCES}

Carratu, L., Franceschelli, S., Pardini, C. L., Kobayashi, G. S., Horvath, I., Vigh, L. \& Maresca, B. (1996). Membrane lipid perturbation modifies the set point of the temperature of heat shock response in yeast. Proc Natl Acad Sci USA 93, 3870-3875.

Cheng, L. \& Piper, P. W. (1994). Weak acid preservatives block the heat shock response and heat-shock-element-directed lacZ expression of low pH Saccharomyces cerevisiae cultures, an inhibitory action partially relieved by respiratory deficiency. Microbiology 140, 1085-1096.

Coote, P. J., Jones, M. V., Seymour, I. J., Rowe, D. L., Ferdinando, D. P., McArthur, A. J. \& Cole, M. B. (1994). Activity of plasma membrane $\mathrm{H}^{+}$-ATPase is a key physiological determinant of thermotolerance in Saccharomyces cerevisiae. Microbiology 140, 1881-1890.

Curran, B. P. G. \& Khalawan, S. A. (1994). Alcohols lower the threshold temperature for the maximal activation of a heat shock expression vector in the yeast Saccharomyces cerevisiae. Microbiology 140, 2225-2228.

Hossack, J. A. \& Rose, A. H. (1976). Fragility of plasma membranes in Saccharomyces cerevisiae enriched with different sterols. $J$ Bacteriol 127, 67-75.

Hunter, K. \& Rose, A. H. (1972). Lipid composition of Saccharomyces cerevisiae as influenced by growth temperature. Biochim Biophys Acta 260, 639-653.

Lewis, J. G., Learmonth, R. P. \& Watson, K. (1995). Induction of heat, freezing and salt tolerance by heat and salt shock in Saccharomyces cerevisiae. Microbiology 141, 687-694.

Lloyd, D., Morrell, S., Carlsen, H. N., Degn, H., James, P. E. \& Rowlands, C. C. (1993). Effects of growth with ethanol on fermentation and membrane fluidity of Saccharomyces cerevisiae. Yeast 9, 825-833.

Mager, W. H. \& Ferreira, P. M. (1993). Stress response of yeast. Biochem J 290, 1-13.

Miller, M. J., Xuong, N. \& Geiduschek, E. P. (1979). A response of protein synthesis to temperature shift in the yeast Saccharomyces cerevisiae. Proc Natl Acad Sci USA 76, 5222-5225.

Panaretou, B. \& Piper, P. W. (1990). Plasma-membrane ATPase action affects several stress tolerances of Saccharomyces cerevisiae and Schizosaccharomyces pombe as well as the extent and duration of the heat shock response. J Gen Microbiol 136, 1763-1770.
Parsell, D. A. \& Lindquist, S. (1993). The function of heat shock proteins in stress tolerance: degradation and reactivation of damaged proteins. Annu Rev Genet 27, 437-496.

Pelham, H. R. B. \& Bienz, M. (1982). A synthetic heat shock promoter element confers heat-inducibility on the herpes-simplex virus thymidine kinase gene. EMBO J 1, 1473-1477.

Piper, P. W. (1993). Molecular events associated with the acquisition of heat tolerance in the yeast Saccharomyces cerevisiae. FEMS Microbiol Rev 11, 1-11.

Slater, M. R. \& Craig, E. A. (1987). Transcriptional regulation of an $\mathrm{Hsp} 70$ heat shock gene in the yeast Saccharomyces cerevisiae. Mol Cell Biol 7, 1906-1916.

Sorger, P. K. (1990). Yeast heat shock factor contains separable transient and sustained response transcriptional activators. Cell 62, 793-805.

Sorger, P. K. (1991). Heat shock factor and the heat shock response. Cell 65, 363-366.

Sorger, P. K. \& Pelham, H. R. B. (1987). Purification and characterization of a heat-shock element binding protein from yeast. $E M B O ~ J ~ 6,3035-3041$.

Sorger, P. K. \& Pelham, H. R. B. (1988). Yeast heat shock factor is an essential DNA-binding protein that exhibits temperaturedependent phosphorylation. Cell 54, 855-864.

Suutari, M., Liukkonen, K. \& Laakso, S. (1990). Temperature adaptation in yeast: the role of fatty acids. J Gen Microbiol 136, 1469-1474.

Thomas, S., Hossack, J. A. \& Rose, A. H. (1978). Plasma-membrane lipid composition and ethanol tolerance in Saccharomyces cerevisiae. Arch Microbiol 117, 239-245.

Varela, J. C. S., Van Beekvelt, C., Planta, R. J. \& Mager, W. H. (1992). Osmostress-induced changes in yeast gene expression. Mol Microbiol 6, 2183-2190.

Weitzel, G., Pilatus, U. \& Rensing, L. (1987). The cytoplasmic pH, ATP content and total protein synthesis rate during heat shock inducing treatments in yeast. Exp Cell Res 170, 64-79.

Wickerham, L. J. (1951). United States Department of Agriculture Technical Bulletin, no. 1029.

Wiederrecht, G., Seto, D. \& Parker, C. S. (1988). Isolation of the gene encoding the $S$. cerevisiae heat shock transcription factor. Cell 54, 841-853.

Received 9 December 1996; revised 18 April 1997; accepted 27 May 1997. 